\title{
Aspekty prawne odpowiedzialności funkcjonariuszy publicznych
}

\author{
Legal aspects of public officials' liability \\ Правовые аспекты ответственности должностных лиц
}

\author{
BOGDAN JAWORSKI \\ Dr, Uniwersytet Rzeszowski \\ e-mail: hr66@op.pl, https://orcid.org/0000-0001-7372-2803
}

\begin{abstract}
Streszczenie: Administracja publiczna wykonując złożone zadania, dysponuje charakterystycznymi dla niej strukturami organizacyjnymi opartymi w głównej mierze na monokratycznych organach. Funkcjonowanie struktur tej administracji związane jest z istnieniem aparatów pomocniczych jej organów, składających się z komórek organizacyjnych oraz zróżnicowanego pod względem statusu prawnego personelu. Szczególną rolę w działalności administracji odgrywają funkcjonariusze publiczni, którzy przejmują na siebie najistotniejszą część spraw publicznych. Pamiętając, że administracja może podejmować aktywność jedynie w granicach prawa i na podstawie norm prawnych, niezwykle istotne wydaje się działanie funkcjonariuszy publicznych zgodne z określonymi reżimami. Gwarancją takiego stanu rzeczy są liczne przepisy należące do różnych gałęzi prawa, odnoszące się do odpowiedzialności za czyny wykraczające poza te normy. Podjęte w opracowaniu rozważania koncentrują się na zróżnicowanych aspektach odpowiedzialności funkcjonariuszy publicznych.
\end{abstract}

Słowa kluczowe: prawo, administracja, administracja publiczna, funkcjonariusz publiczny, odpowiedzialność

Summary: Public administration perform complex tasks and have characteristic organisational structures mainly based on monocratic bodies. The operation of these structures within this administration is related to the existence of auxiliary apparatuses of its bodies, consisting of organisational units and staff of different legal status. Public officials play a special role in the administration's activities as they are responsible for taking over the most important part of public affairs. Bearing in mind that the administration may undertake activities only within the limits of the law and on the basis of legal norms, it seems particularly important that public officials act in accordance with specific regimes. The guarantee of such a state of affairs is provided by numerous regulations belonging to various branches of law relating to liability for acts exceeding these norms. The considerations undertaken in the study focus on various aspects of public officials' liability.

Key words: law, administration, public administration, public official, responsibility

Резюме: Публичная администрация, выполняя сложные задачи, располагает характерными организационными структурами, основанными в основном на монократических органах. Функционирование этой структуры управления связано с существованием вспомогательных аппаратов ее органов, состоящих из разнообразных по правовому статусу организационных единиц и персонала. Особую роль в деятельности администрации играют должностные лица, которые берут на себя наиболее значительную часть государственных дел. Учитывая, что администрация может осуществлять деятельность только в рамках закона и на основе правовых норм, представляется чрезвычайно важным, чтобы должностные лица действовали в соответствии с установленными режимами. Гарантией такого положения дел являются многочисленные нормативные акты, относящиеся к различным отраслям права, в которых говорится об ответственности за действия, выходящие за пределы этих норм. Предпринятые в исследовании рассуждения касаются различных аспектов ответственности публичных должностных лиц.

Ключевые слова: право, администрация, публичная администрация, должностное лицо, ответственность 


\section{Wstęp}

Sprawnie działające państwo to efektywna administracja, która za pośrednictwem podmiotów wchodzących w jej system wykonuje przypisane do niej specyficzne i zróżnicowane cele i zadania. Administracja to duża grupa pracowników, których istotą funkcjonowania jest służba społeczeństwu oraz zaspokajanie szeregu potrzeb ludzkich. W strukturach podmiotów administracji publicznej istnieją wielorakie grupy pracownicze, które podejmują się działalności różnorodnej pod względem celów oraz ich ciężaru gatunkowego czy ważkości. Ta duża różnorodność powoduje konieczność dokonania pewnej hierarchizacji zadań, a co się z tym wiąże - także podmiotów, którym zostały przypisane określone poruczenia i kompetencje.

Pracownicy i urzędnicy oraz funkcjonariusze stanowią trzon i fundament administracji publicznej, która często utożsamiana jest z władzą wykonawczą. W przepisach prawa nierzadko pojawia się także pojęcie funkcjonariusza publicznego jako podmiotu wyróżniającego się szerokimi uprawnieniami i podejmującego się wykonania zadań, najistotniejszych nie tylko z perspektywy samej organizacji, ale często także państwa. Funkcjonariusze publiczni sprawując funkcje publiczne, obdarzeni zostali władztwem przypisanym dla administracji publicznej, które wykorzystują, stosując bardzo często władcze formy działania. Możliwość np. wydawania aktów administracyjnych powoduje, że oddziałują oni w sposób prawnie wiążący na sytuację prawną jego adresata, kształtując określone stosunki prawne.

Działalność administracji w ramach władztwa dyskrecjonalnego bardzo często stanowi pokusę dla jej funkcjonariuszy do wychodzenia poza normy określone w przepisach prawa lub też do mało wnikliwego czy nierzetelnego prowadzenia określonych postępowań. Wszelka działalność wykraczająca poza przyjęte normy i standardy związana jest z ponoszeniem przez funkcjonariuszy odpowiedzialności, zróżnicowanej pod względem prawnym i rodzajem grożących sankcji. Sama zaś odpowiedzialność funkcjonariuszy stała się nieodzowną cechą stosunku zatrudnienia oraz wyznacznikiem ich statusu w społeczeństwie.

Pozycje słownikowe odpowiedzialność określają jako „obowiązek moralny lub prawny odpowiadania za swoje lub czyjeś czyny”. Ma to również przełożenie w odniesieniu do administracji, której odpowiedzialność jest kojarzona z rozbudowanym systemem mechanizmów gwarantujących, że każde działanie organu czy urzędnika, łamiące przepisy prawa i godzące $\mathrm{w}$ dobro wspólne, nie pozostanie bez reakcji1 ${ }^{1}$ Przy czym odpowiedzialność kojarzona jest $\mathrm{z}$ ujemnymi konsekwencjami podejmowanych

1 R. Kusiak-Winter, Odpowiedzialność administracji publicznej. Struktura odpowiedzialności z perspektywy determinantów prawnych, Wrocław 2019, s. 25. 
działań lub ich braku i związana jest $\mathrm{z}$ określonymi osobami. Pojęcie to obejmuje też dolegliwości wynikające z naganności zachodzących stanów faktycznych².

W nauce prawa termin ten zazwyczaj używany jest jako pojęcie określające pewną dolegliwość przewidzianą w wypadku naruszenia normy prawnej przez określony podmiot ${ }^{3}$. Współcześnie często pojawia się termin accountability określany jako rozliczalność, który dość powszechnie utożsamiany jest z odpowiedzialnością (responsibility). Można rzecz jasna zająć stanowisko, że pojęcie rozliczalności jest tożsame z klasycznym pojęciem odpowiedzialności ${ }^{4}$. Rozliczalność jest jednak wyrażeniem dość ogólnym odnoszącym się do wielu zjawisk i procesów w administracji. Na podstawie wnikliwej analizy tych terminów należy jednak podzielić pogląd prezentowany przez J. Supernata o rozłączności rozliczalności i odpowiedzialności.

Administracja publiczna działa poprzez pracowników, stanowiących aparat pomocniczy organów tej administracji, dlatego odpowiedzialność służyć ma doskonaleniu pracy tych pracowników oraz stanowić gwarancje prawidłowego wykonywania przez nich obowiązków 5 . Prawny kształt odpowiedzialności pracownika jest wypadkową dwóch czynników: rozszerzenia zakresu i obowiązków administracji jako takiej (co jest równoznaczne z potrzebą rozszerzenia jej odpowiedzialności także prawnej) i zakazu przerzucania na funkcjonariusza rosnącego ryzyka administrowania w takich warunkach ${ }^{6}$. Mówiąc o odpowiedzialności prawnej, przytoczyć należy pogląd prezentowany przez W. Langa, według którego „odpowiedzialność” w najszerszym znaczeniu zarówno na gruncie przepisów prawa, jak i nauki prawa znaczy we wszystkich dyscyplinach prawniczych zasadę ponoszenia przez podmiot przewidzianych prawem ujemnych konsekwencji za zdarzenia lub stany rzeczy podlegające ujemnej kwalifikacji normatywnej i przypisywalne prawnie określonemu podmiotowi w danym porządku prawnym ${ }^{7}$.

Wyznacznikiem odpowiedzialności są przesłanki wskazujące na naruszenie określonych norm, co z kolei powiązane jest z negatywnymi dolegliwościami dla

2 E. Ura, Prawo urzędnicze, Warszawa 2004, s. 203.

3 E. Ura, Odpowiedzialność pracowników administracji, Rzeszów 2009, s. 13; por. W. Sanetra, Odpowiedzialność pracownika administracji, w: Pracownicy administracji w PRL, red. J. Łętowski, Warszawa 1984, s. 381-382.

4 J. Supernat, O pojęciu rozliczalności (accountability) administracji, w: Odpowiedzialność administracji i $w$ administracji, red. Z. Duniewska, M. Stahl, Warszawa 2013, s. 36.

5 E. Ura, Odpowiedzialność..., s. 13.

6 E. Łętowska, Prawna odpowiedzialność funkcjonariusza administracji w państwach socjalistycznych, w: Odpowiedzialność pracownika administracji, red. J. Łętowski, Wrocław-Warszawa-KrakówGdańsk 1978, s. 77.

7 W. Lang, Struktura odpowiedzialności prawnej (studium analityczne z dziedziny teorii prawa), Zeszyty Naukowe Uniwersytetu Mikołaja Kopernika. Nauki Humanistyczno-Społeczne. Prawo 1968, t. 8, z. 31, s. 12 . 
sprawców. W literaturze przedmiotu wskazuje się na elementy konstrukcyjne każdego rodzaju odpowiedzialności prawnej, którymi są przesłanki odpowiedzialności, zakres podmiotowy i przedmiotowy, rodzaj grożących sankcji i organy uprawnione do ich stosowania, a także kwestie procesowe.

Na podstawie dokonanej analizy przepisów prawa odnoszących się do szeroko rozumianych urzędników i funkcjonariuszy publicznych można dokonać rozgraniczenia na kilka rodzajów odpowiedzialności. Najogólniej rzecz ujmując, funkcjonariusze publiczni podlegają odpowiedzialności wynikającej z przepisów zaliczanych do różnych gałęzi prawa. Wyróżnić należy odpowiedzialność administracyjną, karną, cywilną oraz wynikającą z przepisów prawa pracy czy prawa stosunków służbowych, która zbiorczo określana jest jako dyscyplinarna.

Przedmiotem podjętych badań jest rodzajowość odpowiedzialności funkcjonariuszy publicznych za działania lub zaniechania oraz konsekwencje prawne tych negatywnych zachowań. Przystępując do rozważań odnoszących się do aspektów prawnych odpowiedzialności, należy postawić hipotezę, że współczesne prawodawstwo w sposób całościowy reguluje uwarunkowania i procedury oraz sankcje stosowane za niewłaściwe postawy funkcjonariuszy publicznych. Kompleksowe odniesienie się do odpowiedzialności funkcjonariuszy publicznych wymaga jednak multidyscyplinarnego spojrzenia na analizowaną problematykę. Mając na uwadze wnikliwość badawczą, należy ograniczyć badania wyłącznie do i tak szerokiej grupy funkcjonariuszy publicznych, których istotę kształtują definicje prawne. W tym celu w pierwszej kolejności zwrócić trzeba uwagę na samo pojęcie funkcjonariusza publicznego.

\section{Funkcjonariusz publiczny}

W polskim porządku prawnym funkcjonują legalne definicje funkcjonariusza publicznego, przy czym ustawodawca wykazał się brakiem zgodności terminologicznej co do tego pojęcia. Analizując przepisy prawa, można doszukać się dwóch definicji: pierwsza wynika z ustawy Kodeks $\mathrm{karny}^{8}$, a druga z ustawy o odpowiedzialności majątkowej funkcjonariuszy publicznych za rażące naruszenie prawa9 ${ }^{9}$

\footnotetext{
8 Ustawa z dnia 6 czerwca 1997 r. - Kodeks karny, tekst jednolity: Dz. U. z 2020 r. poz. 1444 (dalej: K.k.).

9 Ustawa z dnia 20 stycznia 2011 r. o odpowiedzialności majątkowej funkcjonariuszy publicznych za rażące naruszenie prawa, tekst jednolity: Dz. U. z 2016 r. poz. 1169.
} 
Na gruncie prawa karnego pojęcie funkcjonariusza publicznego przyjęło postać enumeratywnego wyliczenia podmiotów spełniających przesłanki do przyporządkowania ich do tego terminu prawnego. Zgodnie $\mathrm{z}$ art. $115 \$ 13 \mathrm{~K} . \mathrm{k}$.

funkcjonariuszem publicznym jest: Prezydent Rzeczypospolitej Polskiej; poseł, senator, radny; poseł do Parlamentu Europejskiego; sędzia, lawnik, prokurator, funkcjonariusz finansowego organu postępowania przygotowawczego lub organu nadrzędnego nad finansowym organem postępowania przygotowawczego, notariusz, komornik, kurator sądowy, syndyk, nadzorca sądowy i zarządca, osoba orzekająca w organach dyscyplinarnych działających na podstawie ustawy; osoba będąca pracownikiem administracji rządowej, innego organu państwowego lub samorządu terytorialnego, chyba że pełni wyłącznie czynności usługowe, a także inna osoba w zakresie, w którym uprawniona jest do wydawania decyzji administracyjnych; osoba będąca pracownikiem organu kontroli państwowej lub organu kontroli samorządu terytorialnego, chyba że pełni wyłącznie czynności usługowe; osoba zajmująca kierownicze stanowisko w innej instytucji państwowej; funkcjonariusz organu powołanego do ochrony bezpieczeństwa publicznego albo funkcjonariusz Służby Więziennej; osoba pełniąca czynną służbę wojskową, z wyjątkiem terytorialnej służby wojskowej pełnionej dyspozycyjnie; pracownik międzynarodowego trybunału karnego, chyba że pełni wyłącznie czynności usługowe.

Ten szeroki krąg podmiotów w zdecydowanej mierze wykracza poza doktrynalne pojęcie administracji publicznej i zmierza w stronę całego trójstopniowego podziału władzy w Polsce. Zbliżone stanowisko odnoszące się do funkcjonariusza publicznego prezentowane jest w literaturze dotyczącej prawa policyjnego ${ }^{10}$. Pamiętać należy jednak, że ustawodawca ograniczył stosowanie tegoż przepisu wyłącznie do odpowiedzialności karnej.

Druga definicja funkcjonariusza publicznego $\mathrm{w}$ polskim systemie prawa jest definicją krótszą, zwięźlejszą, a także węższą w zakresie podmiotowym niż definicja funkcjonariusza publicznego zawarta w K.k., co jest oczywiste ze względu na cel ustawy, w której się znajduje ${ }^{11}$. Na gruncie administracyjnoprawnym zastosowanie ma terminologia wynikająca ze wspomnianej już ustawy o odpowiedzialności majątkowej funkcjonariuszy publicznych za rażące naruszenie prawa. Art. 2 ust. 1 pkt 1 wskazuje na funkcjonariusza publicznego jako na

osobę działającą w charakterze organu administracji publicznej lub z jego upoważnienia albo jako członek kolegialnego organu administracji publicznej lub osobę wykonującą

10 Por. M. Dzimińska-Mosio, Funkcjonariusz publiczny, w: Leksykon policyjny, red. W. Pływaczewski, G. Kędzierska, Szczytno 2001.

11 F. Freitag, Członkowie Rady Ministrów - funkcjonariusze publiczni, w: Odpowiedzialność prawna funkcjonariuszy publicznych. Wybrane zagadnienia, red. M. Giżyńska, D. Ossowska-Salamonowicz, F. Freitag, M. Malessa, K. Pawikowski, Olsztyn 2017, s. 169. 
w urzędzie organu administracji publicznej pracę w ramach stosunku pracy, stosunku służbowego lub umowy cywilnoprawnej, biorącą udział w prowadzeniu sprawy rozstrzyganej w drodze decyzji lub postanowienia przez taki organ.

Uwzględniając tę definicję, wyszczególnić należy funkcjonariuszy, których stosunek zatrudnienia regulują przepisy prawa pracy, prawa cywilnego oraz tych, których zatrudnienie przybiera postać stosunku administracyjnoprawnego ${ }^{12}$. Takie ujęcie z kolei dopełnia postawione na wstępie założenie o rodzajowości odpowiedzialności funkcjonariuszy publicznych.

W gronie tak rozumianych funkcjonariuszy publicznych swoje miejsce znajdują także funkcjonariusze tzw. służb mundurowych i żołnierze. W tych przypadkach również przepisy rangi ustawowej, odnoszące się jedynie do odpowiedzialności majątkowej, określają, kto jest funkcjonariuszem, a kto żołnierzem. Mówiąc o funkcjonariuszu - należy przez to rozumieć: policjanta, funkcjonariusza Straży Granicznej, funkcjonariusza Straży Marszałkowskiej, funkcjonariusza Służby Celno-Skarbowej, funkcjonariusza Służby Ochrony Państwa, strażaka Państwowej Straży Pożarnej, funkcjonariusza Służby Więziennej, funkcjonariusza Agencji Bezpieczeństwa Wewnętrznego, Agencji Wywiadu, Służby Kontrwywiadu Wojskowego, Służby Wywiadu Wojskowego oraz Centralnego Biura Antykorupcyjnego ${ }^{13}$.

Z kolei ustawa o odpowiedzialności majątkowej żołnierzy wskazuje, że przez

żołnierza należy rozumieć żołnierza w czynnej służbie wojskowej, o którym mowa w ustawie z dnia 11 września 2003 r. o służbie wojskowej żołnierzy zawodowych i w ustawie z dnia 21 listopada 1967 r. o powszechnym obowiązku obrony Rzeczypospolitej Polskiej, z wyjątkiem żołnierza pełniącego terytorialną służbę wojskową dyspozycyjnie ${ }^{14}$.

Przedstawione ujęcia funkcjonariusza publicznego należy rozpatrywać łącznie z tymi wynikającymi z przepisów odnoszących się do korpusów urzędniczych czy też z Kodeksu pracy ${ }^{15}$.

12 B. Jaworski, Przekształcenie stosunku służbowego funkcjonariuszy, w: Bezpieczeństwo w prawie administracyjnym, red. M. Lewicki, Łódź 2019.

13 Art. 1 ust. 2 pkt 1 ustawy z dnia 7 maja 1999 r. o odpowiedzialności majątkowej funkcjonariuszy Policji, Straży Granicznej, Straży Marszałkowskiej, Służby Celno-Skarbowej, Służby Ochrony Państwa, Państwowej Straży Pożarnej, Służby Więziennej, Agencji Bezpieczeństwa Wewnętrznego, Agencji Wywiadu, Służby Kontrwywiadu Wojskowego, Służby Wywiadu Wojskowego i Centralnego Biura Antykorupcyjnego, tekst jednolity: Dz. U. z 2018 r. poz. 2349.

14 Art. 2 pkt 1 ustawy z dnia 25 maja 2001 r. o odpowiedzialności majątkowej żołnierzy, tekst jednolity: Dz. U. z 2018 r. poz. 85.

15 Ustawa z dnia 26 czerwca 1974 r. - Kodeks pracy, tekst jednolity: Dz. U. z 2020 r. poz. 1320 (dalej: K.p.). 
Funkcjonariusz publiczny to podmiot korzystający na podstawie polskiego prawa karnego ze szczególnej ochrony prawnej i podlegający szczególnej odpowiedzialności prawnej, $\mathrm{z}$ uwagi na pozycję zawodową lub posiadane kompetencje związane ze sprawowaniem władzy publicznej ${ }^{16}$. Żeby mówić o odpowiedzialności funkcjonariuszy publicznych, konieczne jest dokonanie analiz na kilku płaszczyznach. Wydaje się, że najszerszy zakres odpowiedzialności płynie z norm administracyjnoprawnych, dlatego w pierwszej kolejności przybliżyć należy ten obszar.

\section{Odpowiedzialność administracyjna}

Odpowiedzialność administracyjna jest rodzajem odpowiedzialności prawnej, której istota wyraża się w ponoszeniu przez podmiot prawa ujemnej w skutkach konsekwencji niedostosowania się adresata normy prawnej do nałożonego obowiązku ${ }^{17}$. W przypadku tej odpowiedzialności, w sytuacji spełnienia określonych przesłanek prawnych przez dany podmiot, istnieje możliwość zastosowania przez uprawniony organ sankcji wynikających z przepisów prawa. Sankcje te ulegają podziałowi na represyjne oraz pojawiające się w postępowaniu przymusowym, czyli mające postać egzekucyjną.

Aktem normatywnym, który niejako otwiera możliwość pociągnięcia do odpowiedzialności funkcjonariuszy publicznych, jest ustawa - Kodeks postępowania administracyjnego ${ }^{18}$. Zgodnie z art. 38 K.p.a.

pracownik organu administracji publicznej podlega odpowiedzialności porządkowej lub dyscyplinarnej albo innej odpowiedzialności przewidzianej w przepisach prawa, jeżeli z nieuzasadnionych przyczyn nie załatwił sprawy w terminie lub prowadził postępowanie dłużej niż było to niezbędne do załatwienia sprawy.

Przewidziana $\mathrm{w}$ ustawie odpowiedzialność administracyjna znajduje swoje odniesienie także w innych aktach ustawowych zawierających normy prawa administracyjnego.

16 M. Adamczyk, Funkcjonariusz publiczny, w: Słownik pojęć w administracji publicznej, red. I. Wieczorek, J. Szymanek, Łódź 2018, s. 78.

17 K. Prokop, Odpowiedzialność administracyjna, w: Słownik pojęć w administracji publicznej, red. I. Wieczorek, J. Szymanek, Łódź 2018, s. 145.

18 Ustawa z dnia 14 czerwca 1960 r. - Kodeks postępowania administracyjnego, tekst jednolity: Dz. U. z 2020 r. poz. 256 z późn. zm. (dalej: K.p.a.). 
Kluczowego znaczenia w tym względzie nabierają przepisy ustawy o odpowiedzialności majątkowej funkcjonariuszy publicznych za rażące naruszenie prawa. Ustawa wskazuje na zasady odpowiedzialności majątkowej funkcjonariuszy publicznych wobec podmiotów odpowiedzialnych, którymi są Skarb Państwa, jednostki samorządu terytorialnego oraz inne podmioty ponoszące odpowiedzialność za szkodę wyrządzoną przy wykonywaniu władzy publicznej. Odpowiedzialność ta ograniczona została wyłącznie do działań lub zaniechania działania skutkujących rażącym naruszeniem prawa. Warunkiem ponoszenia odpowiedzialności majątkowej przez funkcjonariusza publicznego jest łączne spełnienie następujących ustawowych przesłanek:

1) na mocy prawomocnego orzeczenia sądu lub na mocy ugody zostało wypłacone przez podmiot odpowiedzialny odszkodowanie za szkodę wyrządzoną przy wykonywaniu władzy publicznej z rażącym naruszeniem prawa;

2) rażące naruszenie prawa zostało spowodowane zawinionym działaniem lub zaniechaniem funkcjonariusza publicznego;

3) rażące naruszenie prawa zostało stwierdzone zgodnie z przepisami ustawy ${ }^{19}$.

19 Zgodnie z art. 6 ustawy o odpowiedzialności majątkowej funkcjonariuszy publicznych za rażące naruszenie prawa: „przez stwierdzenie rażącego naruszenia prawa należy rozumieć: 1) wydanie ostatecznej decyzji stwierdzającej nieważność decyzji lub postanowienia na podstawie art. 156 $\$ 1$ pkt 2 lub art. $156 \$ 1$ pkt 2 w związku z art. 126 ustawy z dnia 14 czerwca 1960 r. - Kodeks postępowania administracyjnego; 2) wydanie ostatecznej decyzji stwierdzającej nieważność decyzji lub postanowienia na podstawie art. $247 \$ 1$ pkt 2 albo pkt 3 lub art. $247 \$ 1$ pkt 2 albo pkt 3, w związku z art. 219 ustawy z dnia 29 sierpnia 1997 r. - Ordynacja podatkowa; 3) stwierdzenie braku podstawy prawnej lub rażącego naruszenia prawa na podstawie art. $54 \$ 3$ ustawy z dnia 30 sierpnia 2002 r. - Prawo o postępowaniu przed sądami administracyjnymi; 4) wydanie prawomocnego wyroku na podstawie art. $145 \$ 1$ pkt 2 ustawy z dnia 30 sierpnia 2002 r. Prawo o postępowaniu przed sądami administracyjnymi w związku z art. $156 \$ 1$ pkt 2 ustawy z dnia 14 czerwca 1960 r. - Kodeks postępowania administracyjnego; 5) wydanie prawomocnego wyroku na podstawie art. $145 \$ 1$ pkt 2 ustawy z dnia 30 sierpnia 2002 r. - Prawo o postępowaniu przed sądami administracyjnymi w związku z art. $247 \$ 1$ pkt 2 albo 3 ustawy z dnia 29 sierpnia 1997 r. - Ordynacja podatkowa; 6) stwierdzenie rażącego naruszenia prawa na podstawie art. $37 \$ 2$ ustawy $z$ dnia 14 czerwca 1960 r. - Kodeks postępowania administracyjnego; 7) stwierdzenie rażącego naruszenia prawa na podstawie art. $141 \S 2$ ustawy z dnia 29 sierpnia 1997 r. Ordynacja podatkowa; 8) prawomocne stwierdzenie rażącego naruszenia prawa na podstawie art. 149 lub art. $154 \$ 2$ ustawy z dnia 30 sierpnia 2002 r. - Prawo o postępowaniu przed sądami administracyjnymi; 9) prawomocne stwierdzenie rażącego naruszenia prawa na podstawie art. $477^{14} \S 3$ ustawy z dnia 17 listopada 1964 r. - Kodeks postępowania cywilnego; 10) prawomocne stwierdzenie braku podstawy prawnej lub rażącego naruszenia prawa na podstawie art. $479^{31 a}$ $\$ 3$ ustawy z dnia 17 listopada 1964 r. - Kodeks postępowania cywilnego; 11) ostateczne stwierdzenie braku podstawy prawnej lub rażącego naruszenia prawa na podstawie art. 81 ust. 3 ustawy z dnia 16 lutego 2007 r. o ochronie konkurencji i konsumentów. 
Ustawodawca nie określił, czym jest rażące naruszenie prawa, wskazał jednak na sytuacje, w których dochodzi do jego stwierdzenia. Liczne orzeczenia sądów administracyjnych doprecyzowują ten termin, czego przykładem może być wyrok NSA w Warszawie z dnia 17 listopada 2016 r. Zdaniem sądu

rażące naruszenie prawa, określa się jako oczywiste naruszenie przepisu prawa, a przy tym takie, które koliduje z zasadą praworządnego działania organów administracji publicznej w demokratycznym państwie prawnym urzeczywistniającym zasady sprawiedliwości społecznej. Rażące naruszenie prawa oznacza wadliwość decyzji skutkiem naruszenia norm prawnych regulujących działania administracji publicznej w indywidualnych sprawach, w szczególności przepisów prawa procesowego oraz materialnego, o szczególnym ciężarze gatunkowym. Zachodzi więc w przypadku, gdy czynność zmierzająca do wydania decyzji administracyjnej oraz treść załatwienia sprawy w niej wyrażona stanowią zaprzeczenie stanu prawnego sprawy w całości lub części. Nie chodzi przy tym o błędy w wykładni prawa, lecz o przekroczenie prawa w sposób jasny i niedwuznaczny ${ }^{20}$.

W tym przypadku odpowiedzialność majątkowa funkcjonariusza publicznego związana jest $\mathrm{z}$ wysokością wypłaconego odszkodowania przez podmiot odpowiedzialny. W myśl art. 9 ust. 1 odszkodowanie ustala się w wysokości wypłaconej rekompensaty, jednak nie może ono przewyższać kwoty dwunastokrotności miesięcznego wynagrodzenia przysługującego funkcjonariuszowi publicznemu. Podmiotem zobowiązanym do przeprowadzenia czynności wyjaśniających jest prokurator okręgowy, samo postępowanie sądowe zaś toczy się według przepisów ustawy z dnia 17 listopada 1964 r. - Kodeks postępowania cywilnego ${ }^{21}$. Zaznaczyć należy, że dopuszczalne jest dobrowolne spełnienie świadczenia przez funkcjonariusza publicznego w określonym terminie, nie krótszym jednak niż 7 dni od dnia otrzymania wezwania.

Tryb administracyjnoprawny przybiera również postępowanie o odpowiedzialności za naruszenie dyscypliny finansów publicznych. Podstawą do prowadzenia tego postępowania są przepisy ustawy z dnia 17 grudnia 2004 r. o odpowiedzialności za naruszenie dyscypliny finansów publicznych ${ }^{22}$. W ocenie Naczelnego Sądu Administracyjnego postępowanie o odpowiedzialności za naruszenie dyscypliny

20 Wyrok NSA w Warszawie z dnia 17 listopada 2016 r., II OSK 2983/15, CBOSA.

21 Ustawa z dnia 17 listopada 1964 r. - Kodeks postępowania cywilnego, tekst jednolity: Dz. U. z 2019 r. poz. 1460 z późn. zm. (dalej: K.p.c.).

22 Ustawa z dnia 17 grudnia 2004 r. o odpowiedzialności za naruszenie dyscypliny finansów publicznych, tekst jednolity: Dz. U. z 2019 r. poz. 1440 z późn. zm. 
finansów publicznych toczy się w trybie administracyjnym, tyle że znajduje oparcie w przepisach ustawy szczególnej, nie zaś w przepisach ogólnych K.p.a. ${ }^{23}$.

Katalog podmiotów odpowiedzialnych za naruszenie dyscypliny finansów publicznych wynika $\mathrm{z}$ art. 4 ustawy, zgodnie z nim są to: osoby wchodzące w skład organu wykonującego budżet lub plan finansowy jednostki sektora finansów publicznych albo organu zarządzającego podmiotu niezaliczanego do sektora finansów publicznych, któremu przekazano do wykorzystania lub dysponowania środki publiczne, lub zarządzającego mieniem tych jednostek lub podmiotów; kierownicy jednostek sektora finansów publicznych; pracownicy jednostek sektora finansów publicznych lub inne osoby, którym odrębną ustawą lub na jej podstawie powierzono wykonywanie obowiązków w takiej jednostce, których niewykonanie lub nienależyte wykonanie stanowi czyn naruszający dyscyplinę finansów publicznych; osoby wykonujące w imieniu podmiotu niezaliczanego do sektora finansów publicznych, któremu przekazano do wykorzystania lub dysponowania środki publiczne, czynności związane z wykorzystaniem tych środków lub dysponowaniem tymi środkami.

Czyny podlegające odpowiedzialności za naruszenie dyscypliny finansów publicznych określone zostały w art. 5 do art. 18c ustawy. Odpowiedzialność za naruszenie dyscypliny finansów publicznych przypisana została do osoby, która popełniła czyn wyczerpujący znamiona tego naruszenia określony w przepisach ustawy obowiązującej w czasie jego popełnienia. Karami za naruszenie dyscypliny finansów publicznych są: upomnienie; nagana; kara pieniężna; zakaz pełnienia funkcji związanych z dysponowaniem środkami publicznymi.

Karę pieniężną wymierza się w wysokości od 0,25 do 3-krotności miesięcznego wynagrodzenia osoby odpowiedzialnej za naruszenie dyscypliny finansów publicznych, kara zakazu pełnienia funkcji związanych $z$ dysponowaniem środkami publicznymi zaś może być orzeczona na okres od roku do pięciu lat ${ }^{24}$.

Omawiając odpowiedzialność administracyjną funkcjonariuszy publicznych, zasygnalizować trzeba, że w odniesieniu do funkcjonariuszy służb mundurowych i żołnierzy funkcjonują dodatkowe uregulowania odnoszące się do odpowiedzialności majątkowej. Ustawa z dnia 7 maja 1999 r. o odpowiedzialności majątkowej funkcjonariuszy Policji, Straży Granicznej, Straży Marszałkowskiej, Służby Celno-Skarbowej, Służby Ochrony Państwa, Państwowej Straży Pożarnej, Służby Więziennej, Agencji Bezpieczeństwa Wewnętrznego, Agencji Wywiadu, Służby Kontrwywiadu Wojskowego, Służby Wywiadu Wojskowego i Centralnego Biura Antykorupcyjnego normuje odpowiedzialność majątkową funkcjonariuszy tych

23 Postanowienie NSA z dnia 22 września 2011 r., II GSK 1595/11, CBOSA.

24 Szerzej art. 31 ustawy o odpowiedzialności za naruszenie dyscypliny finansów publicznych. 
formacji za szkody wyrządzone przez nich, wskutek niewykonania lub nienależytego wykonania obowiązków służbowych, w mieniu Skarbu Państwa znajdującym się $w$ dyspozycji organu lub jednostek organizacyjnych podległych, podporządkowanych albo nadzorowanych przez ministrów właściwych do spraw wewnętrznych, do spraw finansów publicznych, Ministra Obrony Narodowej, Marszałka Sejmu, Ministra Sprawiedliwości, Szefa Agencji Bezpieczeństwa Wewnętrznego, Szefa Agencji Wywiadu, Szefa Służby Kontrwywiadu Wojskowego, Szefa Służby Wywiadu Wojskowego i Szefa Centralnego Biura Antykorupcyjnego.

Z kolei odpowiedzialność majątkową żołnierzy za szkody wyrządzone przez nich, wskutek niewykonania lub nienależytego wykonania obowiązków służbowych, w mieniu Skarbu Państwa znajdującym się w dyspozycji komórek organizacyjnych Ministerstwa Obrony Narodowej oraz jednostek organizacyjnych podporządkowanych albo nadzorowanych przez Ministra Obrony Narodowej, reguluje ustawa z dnia 25 maja 2001 r. o odpowiedzialności majątkowej żołnierzy.

$\mathrm{Z}$ uwagi na specyfikę regulowanych zagadnień oraz ograniczoną grupę adresatów, a także ramy dysertacji pominięto szczegółowe aspekty odpowiedzialności majątkowej funkcjonariuszy służb mundurowych. Podkreślić jednak trzeba, że analizowana w tej części odpowiedzialność administracyjna stanowi dość złożone kwestie, w głównej mierze związane ze sferą stosunków finansowo-materialnych administracji.

\section{Rodzaje odpowiedzialności karnej}

W przypadku gdy przepisy z innych dyscyplin prawa okażą się niewystarczające, przy spełnieniu przesłanek prawnych, funkcjonariusz publiczny podlega odpowiedzialności przewidzianej w prawie karnym. Wykorzystywanie publicznych stanowisk do osiągania prywatnych korzyści to problem, który występuje w mniejszym lub większym zakresie na całym świecie, wyjątkiem nie jest także Polska ${ }^{25}$. Przestępstwa popełniane przez funkcjonariuszy publicznych w głównej mierze zaliczane są do tzw. grupy przestępstw urzędniczych, z tym że pojęcie to wykracza poza tradycyjną formę związaną wyłącznie z działalnością pracowników administracji publicznej.

Przepisy ustawy z dnia 6 czerwca 1997 r. - Kodeks karny nie wskazują wprost na czyny stanowiące znamiona przestępstwa popełnianego przez funkcjonariusza

25 A. Makosz, Ł. Sobiech, Odpowiedzialność urzędników, Dziennik Gazeta Prawna, Warszawa 2011, s. 12. 
publicznego, którego definicja na potrzeby procesu karnego zawarta została w ustawie. Analizując jednak zawarte w K.k. normy prawne, można dojść do wniosku, że część z nich odnosi się do funkcjonariuszy publicznych, z tym że przybierają one dwie postacie, pierwsza ma na celu ochronę funkcjonariuszy, a druga część to przepisy zawierające sankcje za sprzeczne z prawem działania związane ze sprawowaną funkcją. Ponadto jest tak, że jego znaczenie jest tu dwojakie, a mianowicie przede wszystkim powinno ono spełniać rolę zapobiegawczą w takim sensie, że samo istnienie stosownych przepisów przewidujących odpowiedzialność karną za przedmiotowe zachowania okaże się wystarczające dla zapobieżenia ich wystąpieniu, a gdyby tak jednak nie było, to pociągnięcie na ich podstawie do odpowiedzialności sprawców zamachów w tym zakresie sprawi, że przynajmniej zrealizuje się wobec nich odpowiedzialność karna, co także może mieć walor prewencyjny tak w wymiarze indywidualnym, jak i ogólnospołecznym ${ }^{26}$.

Mówiąc o odpowiedzialności karnej funkcjonariuszy publicznych, zasadne jest stosowanie pewnych rozgraniczeń i klasyfikacji przestępstw przez nich popełnianych. Na potrzeby niniejszych rozważań można dokonać podziału na wspomniane już przestępstwa urzędnicze, czyli np. sprzedajność i przekupstwo; przestępstwa przeciwko ochronie informacji i ochronie danych osobowych oraz przestępstwa przeciwko wiarygodności dokumentów. W tym względzie zasadne jest zwrócenie uwagi na przestępstwa, które najczęściej pojawiają się przy okazji działań podejmowanych przez funkcjonariuszy publicznych.

W pierwszej kolejności zwrócić trzeba uwagę na „przestępstwa przeciwko działalności instytucji państwowych oraz samorządu terytorialnego", wśród których znajduje się przestępstwo określane jako łapownictwo, które ulega podziałowi na czynne i bierne. Zgodnie z art. 228 K.k. osoba, która w związku z pełnieniem funkcji publicznej przyjmuje korzyść majątkową lub osobistą albo jej obietnicę, podlega karze grzywny, ograniczenia wolności albo pozbawienia wolności, której maksymalny wymiar może, w zależności od charakteru popełnionego czynu, sięgać nawet do 12 lat. Przestępstwo to określane jest jako łapownictwo bierne, a dla jego bytu istotne jest ustalenie, czy sprawca przyjmuje korzyść albo jej obietnicę w związku z pełnieniem funkcji publicznej. Z kolei łapownictwo czynne, określone w art. 229 K.k., sprowadza się do udzielenia albo złożenia obietnicy udzielenia korzyści majątkowej lub osobistej osobie pełniącej funkcję publiczną w związku z pełnieniem tej funkcji, a sprawca - podobnie jak w poprzednim przypadku - podlega

26 R. Krajewski, Funkcjonariusz publiczny i osoba petniaca funkcje publiczna jako kategorie prawa karnego istotne z perspektywy funkcjonowania administracji publicznej, Studia z Zakresu Prawa, Administracji i Zarządzania UKW 2012, t. 1, s. 9-10. 
karze grzywny, ograniczenia wolności albo pozbawienia wolności maksymalnie do 12 lat. W tym przypadku sprawca może uniknąć kary „jeżeli korzyść majątkowa lub osobista albo ich obietnica zostały przyjęte przez osobę pełniącą funkcję publiczną, a sprawca zawiadomił o tym fakcie organ powołany do ścigania przestępstw i ujawnił wszystkie istotne okoliczności przestępstwa, zanim organ ten o nim się dowiedział"27.

Kolejnym przestępstwem jest tzw. „nadużycie władzy” określone w art. 231 K.k., które polega na przekroczeniu uprawnień, czyli realizacji czynności wychodzących poza kompetencje, lub niedopełnieniu obowiązków sprowadzającym się do niewłaściwego wykonania lub niewywiązania się z obowiązków. Funkcjonariusz publiczny, który przekraczając swoje uprawnienia lub nie dopełniając obowiązków, działa na szkodę interesu publicznego lub prywatnego, podlega karze grzywny, ograniczenia wolności albo pozbawienia wolności w górnej granicy wynoszącej 10 lat. Sąd Najwyższy stwierdził, iż

podkreślenia wymaga, że dla przypisania odpowiedzialności karnej z art. $231 \S 1$ k.k. konieczne jest ustalenie, że sprawca - mający przymiot funkcjonariusza publicznego przekraczając swoje uprawnienia lub nie dopełniając obowiązków działa na szkodę interesu publicznego lub prywatnego. Brak w działaniu (zaniechaniu) funkcjonariusza publicznego któregokolwiek z tych znamion uniemożliwia zakwalifikowanie go jako przestępstwa $^{28}$.

Następna grupa czynów popełnianych przez funkcjonariuszy publicznych to „przestępstwa przeciwko ochronie informacji”, do których zalicza się ujawnianie lub wbrew przepisom ustawy wykorzystywanie informacji niejawnych o klauzuli „tajne” lub „ściśle tajne”. Zgodnie z art. 265 K.k. sprawca tego czynu działający umyślnie podlega karze pozbawienia wolności do lat 8 , w przypadku zaś przestępstwa popełnionego z winy nieumyślnej sankcją jest kara grzywny, ograniczenia wolności albo pozbawienia wolności do roku. Art. 266 K.k. stanowi o przestępstwie polegającym na ujawnianiu osobie nieuprawnionej informacji niejawnej o klauzuli „zastrzeżone” lub „poufne” lub informacji, która uzyskana została w związku z wykonywaniem czynności służbowych, a której ujawnienie może narazić na szkodę prawnie chroniony interes, $\mathrm{w}$ tym przypadku funkcjonariusz publiczny podlega karze pozbawienia wolności do lat 3.

Trzecia grupa to popełniane przez funkcjonariuszy publicznych przestępstwa „przeciwko wiarygodności dokumentów”. Wśród nich na szczególną uwagę

27 Art. $229 \$ 6 \mathrm{~K} . \mathrm{k}$

28 Postanowienie SN z dnia 25 lutego 2003 r., WK 3/03, OSNKW 2003, z. 5-6, poz. 53. 
zasługują tzw. fałszerstwo i poświadczenie nieprawdy. Zgodnie z art. 270 K.k., kto w celu użycia za autentyczny podrabia lub przerabia dokument lub takiego dokumentu jako autentycznego używa, podlega grzywnie, karze ograniczenia wolności albo pozbawienia wolności od 3 miesięcy do lat 5. Z kolei art. 271 K.k. odnosi się do poświadczenia nieprawdy, które polega na poświadczeniu w dokumencie nieprawdy, co do okoliczności mającej znaczenie prawne przez funkcjonariusza publicznego lub inną osobę uprawnioną do jego wystawienia. W tym przypadku sprawcy grozi grzywna, ograniczenie wolności lub pozbawienie wolności nawet do lat 8 , jeżeli czyn został dokonany w celu osiągnięcia korzyści majątkowej lub osobistej.

Przedstawione powyżej przykłady przestępstw funkcjonariuszy publicznych stanowią jedynie pewien wycinek obszernej problematyki odnoszącej się do odpowiedzialności karnej. Problematyka ta zasługuje z pewnością na szczegółowe omówienie w ramach prowadzonych analiz i w kontekście danych statystycznych będących w dyspozycji organów ścigania.

\section{Uwarunkowania odpowiedzialności cywilnej}

Konstytucja Rzeczypospolitej Polskiej ${ }^{29}$ w art. 77 ust. 1 gwarantuje każdej osobie prawo do wynagrodzenia szkody, jaka została mu wyrządzona przez niezgodne z prawem działanie organu władzy publicznej. Dla odpowiedzialności majątkowej funkcjonariusza publicznego, która ma charakter wtórny i regresowy wobec odpowiedzialności władzy publicznej, zasadnicze znaczenie mają regulacje zawarte $\mathrm{w}$ Kodeksie cywilnym ${ }^{30}$. Ogólna podstawa tej odpowiedzialności wynika $\mathrm{z}$ art. 417 K.c. ${ }^{31}$, który w $\$ 1$ wskazuje, że „za szkodę wyrządzoną przez niezgodne z prawem działanie lub zaniechanie przy wykonywaniu władzy publicznej ponosi odpowiedzialność Skarb Państwa lub jednostka samorządu terytorialnego lub inna osoba prawna wykonująca tę władzę z mocy prawa”. Wynikający z tego podmiotowy zakres odpowiedzialności jest zgodny z konstytucyjnym określeniem organu władzy publicznej. Art. 417 K.c. w ślad za art. 77 ust. 1 Konstytucji RP uzależnia odpowiedzialność Skarbu Państwa od przesłanki szkody, związku przyczynowego

29 Konstytucja Rzeczypospolitej Polskiej z dnia 2 kwietnia 1997 r., Dz. U. z 1997 r. Nr 78, poz. 483 z późn. zm.

30 A. Matan, Rażące naruszenie prawa jako przesłanka odpowiedzialności majątkowej funkcjonariusza publicznego, Warszawa 2014, s. 27.

31 Ustawa z dnia 23 kwietnia 1964 r. - Kodeks cywilny, tekst jednolity: Dz. U. z 2019 r. poz. 1145 z późn. zm. (dalej: K.c.). 
oraz niezgodności działania lub zaniechania z normą prawną mającą na celu ochronę naruszonych interesów poszkodowanego ${ }^{32}$.

Normatywne powiązanie odpowiedzialności majątkowej funkcjonariusza publicznego $\mathrm{z}$ odpowiedzialnością władzy publicznej za bezprawne działania (zaniechania) rodzi dwojakiego rodzaju konsekwencje: po pierwsze, co podkreślono wyżej - zakres odpowiedzialności funkcjonariusza jest wyznaczony granicami odpowiedzialności władzy publicznej za bezprawne działania (art. $417 \mathrm{i}$ art. $417^{1}$ $\$ 2$ i 3 K.c.); po drugie - skoro odpowiedzialność majątkowa funkcjonariusza ma charakter regresowy, to należy założyć, że pozostaje ona adekwatna do odpowiedzialności Skarbu Państwa, jednostek samorządu terytorialnego oraz innych osób prawnych wykonujących władzę publiczną, ponoszonej na podstawie przepisów K.c. ${ }^{33}$. Wykonywanie władzy publicznej zestawione jest $\mathrm{z}$ odpowiedzialnością funkcjonariusza publicznego za popełnione czyny niedozwolone, które przybierają postać szkód określonych w art. $417^{1}$ i $417^{2}$ K.c.

Wymienione w art. $417^{1}$ K.c. szkody związane są czynami przyjmującymi postać władczych form działania, takimi jak wydanie aktu normatywnego, wadliwego prawomocnego orzeczenia lub ostatecznej decyzji administracyjnej. Na uwagę zasługuje fakt, że odszkodowanie może przysługiwać w sytuacji podjętego działania, ale także w przypadku bezczynności władzy publicznej.

W myśl art. $417^{1} \S 1$ i 2 Jeżeli szkoda została wyrządzona przez wydanie aktu normatywnego, jej naprawienia można żądać po stwierdzeniu we właściwym postępowaniu niezgodności tego aktu z Konstytucją, ratyfikowaną umową międzynarodową lub ustawą. Jeżeli szkoda została wyrządzona przez wydanie prawomocnego orzeczenia lub ostatecznej decyzji, jej naprawienia można żądać po stwierdzeniu we właściwym postępowaniu ich niezgodności z prawem, chyba że przepisy odrębne stanowią inaczej. Odnosi się to również do wypadku, gdy prawomocne orzeczenie lub ostateczna decyzja zostały wydane na podstawie aktu normatywnego niezgodnego $\mathrm{z}$ Konstytucją, ratyfikowaną umową międzynarodową lub ustawą.

Z kolei $\$ 3$ i 4 stanowi o zaniechaniu działania i powstałymi w związku z tym szkodami. Niewydanie orzeczenia lub decyzji skutkujące wyrządzoną szkodą, gdy obowiązek ich wydania przewiduje przepis prawa, rodzi konsekwencje w postaci żądania jej naprawienia, lecz po stwierdzeniu we właściwym postępowaniu niezgodności z prawem niewydania orzeczenia lub decyzji. W przypadku niewydania aktu

\footnotetext{
32 L. Bosek, Konstytucyjna forma odpowiedzialności odszkodowawczej administracji publicznej, w: Konstytucyjne podstawy funkcjonowania administracji publicznej, red. R. Hauser, Z. Niewiadomski, A. Wróbel, Warszawa 2012, s. 536.

A. Matan, Rażące..., s. 25-26.
} 
normatywnego, którego obowiązek wydania przewiduje przepis prawa, bezprawność takiego stanu stwierdza sąd rozpoznający sprawę o naprawienie szkody.

Zwrócić trzeba uwagę na fragment sfery odpowiedzialności odszkodowawczej niemieszczący się w dotychczas wymienionych, mianowicie na odpowiedzialność za legalne działania administracji, wprowadzony przez przepis art. $417^{2}$ K.c. ${ }^{34}$ Zgodnie $\mathrm{z}$ nim

jeżeli przez zgodne z prawem wykonywanie władzy publicznej została wyrządzona szkoda na osobie, poszkodowany może żądać całkowitego lub częściowego jej naprawienia oraz zadośćuczynienia pieniężnego za doznaną krzywdę, gdy okoliczności, a zwłaszcza niezdolność poszkodowanego do pracy lub jego ciężkie położenie materialne, wskazują, że wymagają tego względy słuszności.

Możliwość wyrządzenia szkody jednostce to ryzyko działalności władczej podejmowanej przez funkcjonariuszy publicznych. Przedstawione uregulowania prawne normują z jednej strony odpowiedzialność cywilną funkcjonariuszy publicznych, a z drugiej - dają osobom poszkodowanym podstawy i gwarancję możliwości naprawiania wyrządzonej im szkody.

\section{Odpowiedzialność na płaszczyźnie dyscyplinarnej}

Odpowiedzialność dyscyplinarna, zwana w dawniejszych regulacjach odpowiedzialnością służbową, jest jedną z instytucji charakteryzujących naturę czy istotę stosunków służbowych ${ }^{35}$. Odpowiedzialność przewidziana za czyn naruszający obowiązki służbowe, zasady etyki czy godności zawodowej jest określana odpowiedzialnością dyscyplinarną ${ }^{36}$. Związana ona jest z ponoszeniem odpowiedzialności przez pracowników wykonujących określony zawód czy osoby sprawujące funkcje publiczne. Jej podstawą w głównej mierze są przepisy prawa publicznego odnoszące się do poszczególnych grup zawodowych, które bardzo często nazywane są pragmatykami służbowymi. Stanowią one o pracowniczym podporządkowaniu i wynikających z tego konsekwencjach oraz uprawnieniach przełożonych właściwych w sprawach dyscyplinarnych.

34 J. Kremis, A. Cisek, J. Boć, Podstawy odpowiedzialności odszkodowawczej za działania administracji, w: Prawo administracyjne, red. J. Boć, Wrocław 2010, s. 438-439.

35 T. Kuczyński, Odpowiedzialność porządkowa i dyscyplinarna, w: Stosunek stużbowy, red. R. Hauser, Z. Niewiadomski, A. Wróbel, Warszawa 2011, s. 438.

M. Adamczyk, Funkcjonariusz publiczny..., s. 147. 
Odpowiedzialność dyscyplinarna funkcjonariuszy publicznych jest problematyką złożoną i zróżnicowaną pod względem organów właściwych do orzekania w sprawach odpowiedzialności porządkowej i dyscyplinarnej, stosowanych kar oraz samej procedury. Postępowanie dyscyplinarne ma charakter represyjny i polega na ustaleniu winnego (winnych) naruszenia określonych norm, również etycznych, dotyczących danej profesji, orzeczenia kary adekwatnej do stopnia zawinienia i jednocześnie ma zniechęcać do niewłaściwych zachowań w przyszłości. Różnorodność profesji, których pracownicy kwalifikowani są do zbiorczego pojęcia funkcjonariusz publiczny, jest bardzo duża, z tej przyczyny odnieść się należy do odpowiedzialności grup reprezentatywnych oraz zwrócić uwagę na podstawowe przepisy ją normujące.

Pracownicy, którzy na podstawie przepisów ustawowych są poddani odpowiedzialności dyscyplinarnej, w zależności od rodzaju przewinienia podlegają również odpowiedzialności porządkowej określonej w ustawie - Kodeks pracy. Art. 108 K.p. przewiduje za nieprzestrzeganie przez pracownika ustalonej organizacji i porządku w procesie pracy, przepisów bezpieczeństwa i higieny pracy, przepisów przeciwpożarowych, a także przyjętego sposobu potwierdzania przybycia i obecności w pracy oraz usprawiedliwiania nieobecności w pracy, możliwość zastosowania przez pracodawcę kary upomnienia lub kary nagany. Pracodawca oprócz wymienionych przypadków, także w sytuacji opuszczenia pracy bez usprawiedliwienia, stawienia się do pracy w stanie nietrzeźwości lub spożywania alkoholu w czasie pracy, ma również prawo do zastosowania kary pieniężnej. Zasadą jest, że lżejsze naruszenia obowiązków pracowniczych skutkują odpowiedzialnością porządkową, za ciężkie przewinienia zaś stosowana jest typowa odpowiedzialność dyscyplinarna.

Przechodząc do odpowiedzialności dyscyplinarnej wybranych grup pracowniczych, w pierwszej kolejności należy się odnieść do korpusu służby cywilnej. Ustawa o służbie cywilnej ${ }^{37} \mathrm{~W}$ rozdziale 9 zawiera normy odnoszące się do odpowiedzialności dyscyplinarnej członka korpusu służby cywilnej, czyli zarówno urzędnika, jak i pracownika. Przesłanki tej odpowiedzialności zostały uregulowane bardzo ogólnie, bo podstawę do odpowiedzialności dyscyplinarnej stanowi naruszenie obowiązków urzędniczych ${ }^{38}$.

W myśl tych przepisów za naruszenie obowiązków członka korpusu służby cywilnej grozi odpowiedzialność dyscyplinarna, skutkująca możliwością stosowania

37 Ustawa z dnia 21 listopada 2008 r. o służbie cywilnej, tekst jednolity: Dz. U. z 2020 r. poz. 265 z późn. zm.

38 M. Szulc, Istota i charakter prawny odpowiedzialności dyscyplinarnej członków służby cywilnej, w: Odpowiedzialność prawna funkcjonariuszy publicznych. Wybrane zagadnienia, red. M. Giżyńska, D. Ossowska-Salamonowicz, F. Freitag, M. Malessa, K. Pawikowski, Olsztyn 2017, s. 86. 
szerokiego katalogu sankcji. Katalog kar dyscyplinarnych wynika z art. 114 ustawy o służbie cywilnej i należą do nich: upomnienie; nagana; pozbawienie możliwości awansowania przez okres dwóch lat na wyższy stopień służbowy; obniżenie wynagrodzenia zasadniczego, nie więcej niż o $25 \%$ - przez okres nie dłuższy niż sześć miesięcy; obniżenie stopnia służbowego służby cywilnej; wydalenie ze służby cywilnej. W stosunku do osób zajmujących wyższe stanowiska w służbie cywilnej oraz pracowników służby cywilnej mogą być wymierzane następujące kary: upomnienie; nagana; obniżenie wynagrodzenia zasadniczego, nie więcej niż o $25 \%$ - przez okres nie dłuższy niż sześć miesięcy; wydalenie z pracy w urzędzie. Ustawodawca przewidział również upomnienie na piśmie, które może być zastosowane przez dyrektora generalnego urzędu za mniejszej wagi naruszenie obowiązków członka korpusu służby cywilnej.

Przesłanki odpowiedzialności dyscyplinarnej urzędnika państwowego są podobne w swym założeniu do przesłanek odpowiedzialności dyscyplinarnych grup zawodowych wynikających $\mathrm{z}$ odrębnych pragmatyk ${ }^{39}$. Zasady odpowiedzialności dyscyplinarnej urzędników państwowych i stosowane sankcje wynikają z przepisów ustawy o pracownikach urzędów państwowych ${ }^{40}$. W świetle tych uregulowań urzędnikom państwowym za naruszenie obowiązków pracownika grozi odpowiedzialność porządkowa lub dyscyplinarna. Przewinienia mniejszej wagi skutkują wymierzeniem kary porządkowej, jaką jest upomnienie, którego udziela kierownik urzędu. Zgodnie z art. 34 ust. 3 ustawy o pracownikach urzędów państwowych karami dyscyplinarnymi są: nagana; nagana $\mathrm{z}$ ostrzeżeniem; nagana $\mathrm{z}$ pozbawieniem możliwości awansowania przez okres do dwóch lat do wyższej grupy wynagrodzenia lub na wyższe stanowisko; przeniesienie na niższe stanowisko; wydalenie z pracy w urzędzie. Orzekanie w sprawach dyscyplinarnych leży w gestii komisji dyscyplinarnych I i II instancji, które są powoływane przez kierowników urzędów, przy których działają.

Status prawny pracowników zatrudnionych w jednostkach samorządu terytorialnego reguluje ustawa o pracownikach samorządowych ${ }^{41}$. Ustawa nie zawiera jednak przepisów o szczególnej odpowiedzialności dyscyplinarnej, w związku z czym pracownicy podlegają odpowiedzialności porządkowej określonej w art. 108 K.p., na co zezwala art. 43 ust. 1 cyt. ustawy, według którego „w sprawach nieuregulowanych

39 E. Ura, Ustawa o pracownikach urzędów państwowych, w: Prawo urzędnicze. Komentarz, red. K.W. Baran, Warszawa 2014, s. 773.

40 Ustawa z dnia 16 września 1982 r. o pracownikach urzędów państwowych, tekst jednolity: Dz. U. z 2020 r. poz. 537.

41 Ustawa z dnia 21 listopada 2008 r. o pracownikach samorządowych, tekst jednolity: Dz. U. z 2019 r. poz. 1282. 
w ustawie stosuje się odpowiednio przepisy Kodeksu pracy". Przesłanką odpowiedzialności dyscyplinarnej pracownika samorządowego jest istotne naruszenie ustawowych obowiązków oraz niezłożenie oświadczenia o prowadzeniu działalności gospodarczej. Zgodnie z art. 24 ust. 1 i 2 ustawy o pracownikach samorządowych do podstawowych obowiązków pracownika samorządowego należy dbałość o wykonywanie zadań publicznych oraz o środki publiczne, z uwzględnieniem interesu publicznego oraz indywidualnych interesów obywateli. Ponadto do obowiązków pracownika samorządowego należy w szczególności: przestrzeganie Konstytucji Rzeczypospolitej Polskiej i innych przepisów prawa; wykonywanie zadań sumiennie, sprawnie i bezstronnie; udzielanie informacji organom, instytucjom i osobom fizycznym oraz udostępnianie dokumentów znajdujących się w posiadaniu jednostki, w której pracownik jest zatrudniony, jeżeli prawo tego nie zabrania; dochowanie tajemnicy ustawowo chronionej; zachowanie uprzejmości i życzliwości w kontaktach z obywatelami, zwierzchnikami, podwładnymi oraz współpracownikami; zachowanie się z godnością w miejscu pracy i poza nim; stałe podnoszenie umiejętności i kwalifikacji zawodowych.

Przedstawione wybrane przykłady uregulowań prawnych kształtujących odpowiedzialność dyscyplinarną funkcjonariuszy publicznych wskazują na dużą różnorodność zastosowanych rozwiązań. Pamiętać trzeba, że w tak szerokiej grupie spełniających zróżnicowane zadania funkcjonariuszy nie jest możliwe zastosowanie jednorodnych reżimów i procedur. Jedno jest w tym istotne, a mianowicie obiektywna ocena stopnia zawinienia, ciężar gatunkowy oraz motywacja sprawcy, tak aby wymierzona kara była adekwatna do popełnionego czynu.

\section{Zakończenie}

Podjęte badania skoncentrowane zostały na ukształtowanym w prawodawstwie i literaturze przedmiotu podziale na odpowiedzialność administracyjną, karną, cywilną i dyscyplinarną funkcjonariuszy publicznych. Każdy z rodzajów odpowiedzialności ma na celu realizację norm prawnych należących do odmiennych dyscyplin prawa oraz poprzez liczne i dolegliwe sankcje skłonienie funkcjonariuszy publicznych do pożądanych zachowań. Dostrzec można również pewne powiązania w szczególności przy odpowiedzialności administracyjnej i cywilnej oraz zbieżność jej celów. Ogólne środki oddziaływania przełożonych na podwładnych stosowa- 
ne do wszystkich pracowników administracji publicznej mają na celu zapewnienie prawidłowego wykonywania przez nich zadań i obowiązków pracowniczych ${ }^{42}$.

Przeprowadzone analizy pozwoliły na potwierdzenie postawionej hipotezy o w miarę pełnym systemie prawnym regulującym warunki odpowiedzialności funkcjonariuszy publicznych i grożących sankcjach, które mają gwarantować rzetelność postaw. Pewnym niekorzystnym zjawiskiem jest duże rozproszenie przepisów prawa i brak jednolitości w przyjętej terminologii, o czym chociażby świadczą dwie różne legalne definicje funkcjonariusza publicznego. Jako wniosek de lege ferenda należy sformułować postulat o potrzebie konsolidacji uregulowań prawnych i stworzeniu jednolitego kodeksu odpowiedzialności funkcjonariusza. Takie rozwiązanie wydaje się trudne do realizacji, jednak każde działanie zmierzające do uproszczenia przyjętych rozwiązań jest warte podjęcia się wysiłku legislacyjnego.

Konstatując, zwróć należy jeszcze uwagę na dolegliwość sankcji, które wprawdzie mają gwarantować zgodne z prawem postawy, lecz niekiedy mogą być niewspółmierne do popełnionego przewinienia. Wydaje się, że nie nadmierna dolegliwość, a nieuchronność kary powinna najbardziej skłaniać funkcjonariuszy do respektowania przyjętego reżimu prawnego. Tylko takie podejście w połączeniu działalnością propagującą właściwe postawy prawne i etyczne może skutkować poprawą jakości służby funkcjonariuszy publicznych.

\section{Bibliografia}

Adamczyk M., Funkcjonariusz publiczny, w: Słownik pojęć w administracji publicznej, red. I. Wieczorek, J. Szymanek, Łódź 2018.

Bosek L., Konstytucyjna forma odpowiedzialności odszkodowawczej administracji publicznej, w: Konstytucyjne podstawy funkcjonowania administracji publicznej, red. R. Hauser, Z. Niewiadomski, A. Wróbel, Warszawa 2012.

Dzimińska-Mosio M., Funkcjonariusz publiczny, w: Leksykon policyjny, red. W. Pływaczewski, G. Kędzierska, Szczytno 2001.

Freitag F., Członkowie Rady Ministrów - funkcjonariusze publiczni, w: Odpowiedzialność prawna funkcjonariuszy publicznych. Wybrane zagadnienia, red. M. Giżyńska, D. Ossowska-Salamonowicz, F. Freitag, M. Malessa, K. Pawikowski, Olsztyn 2017.

Jaworski B., Przekształcenie stosunku służbowego funkcjonariuszy, w: Bezpieczeństwo w prawie administracyjnym, red. M. Lewicki, Łódź 2019.

42 E. Ura, Prawo..., s. 205. 
Krajewski R., Funkcjonariusz publiczny i osoba petniaca funkcję publiczna jako kategorie prawa karnego istotne z perspektywy funkcjonowania administracji publicznej, Studia z Zakresu Prawa, Administracji i Zarządzania UKW 2012, t. 1.

Kremis J., Cisek A., Boć J., Podstawy odpowiedzialności odszkodowawczej za działania administracji, w: Prawo administracyjne, red. J. Boć, Wrocław 2010.

Kuczyński T., Odpowiedzialność porządkowa i dyscyplinarna, w: Stosunek służbowy, red. R. Hauser, Z. Niewiadomski, A. Wróbel, Warszawa 2011.

Kusiak-Winter R., Odpowiedzialność administracji publicznej. Struktura odpowiedzialności $z$ perspektywy determinantów prawnych, Wrocław 2019.

Lang W., Struktura odpowiedzialności prawnej (studium analityczne z dziedziny teorii prawa), Zeszyty Naukowe Uniwersytetu Mikołaja Kopernika. Nauki Humanistyczno-Społeczne. Prawo 1968, t. 8, z. 31.

Łętowska E., Prawna odpowiedzialność funkcjonariusza administracji w państwach socjalistycznych, w: Odpowiedzialność pracownika administracji, red. J. Łętowski i in., Wrocław-Warszawa-Kraków-Gdańsk 1978.

Makosz A., Sobiech Ł., Odpowiedzialność urzędników, Dziennik Gazeta Prawna, Warszawa 2011.

Matan A., Rażące naruszenie prawa jako przesłanka odpowiedzialności majątkowej funkcjonariusza publicznego, Warszawa 2014.

Prokop K., Odpowiedzialność administracyjna, w: Słownik pojęć w administracji publicznej, red. I. Wieczorek, J. Szymanek, Łódź 2018.

Supernat J., O pojęciu rozliczalności (accountability) administracji, w: Odpowiedzialność administracji $i$ w administracji, red. Z. Duniewska, M. Stahl, Warszawa 2013.

Szulc M., Istota i charakter prawny odpowiedzialności dyscyplinarnej członków służby cywilnej, w: Odpowiedzialność prawna funkcjonariuszy publicznych. Wybrane zagadnienia, red. M. Giżyńska, D. Ossowska-Salamonowicz, F. Freitag, M. Malessa, K. Pawikowski, Olsztyn 2017.

Ura E., Prawo urzędnicze, Warszawa 2004.

Ura E., Odpowiedzialność pracowników administracji, Rzeszów 2009.

Ura E., Ustawa o pracownikach urzędów państwowych, w: Prawo urzędnicze. Komentarz, red. K.W. Baran, Warszawa 2014. 
